\title{
Characterization of organic compost from urban pruning waste
}

\author{
Produção e caracterização de composto orgânico proveniente de resíduos da poda arbórea urbana \\ Producción y caracterización de compost orgánico a partir de residuos de poda de árboles urbanos
}

Received: 05/06/2021 | Reviewed: 05/12/2021 | Accept: 05/15/2021 | Published: 06/03/2021

\begin{abstract}
Victória Maria Monteiro Mendonça
ORCID: https://orcid.org/0000-0003-0136-2962

Federal Rural University of Rio de Janeiro, Brazil E-mail: viic_monteiro@hotmail.com

Vitória Duarte S. Silva

ORCID: https://orcid.org/0000-0002-0628-9402 Federal Rural University of Rio de Janeiro, Brazil E-mail: viccduartes@gmail.com

Sidinei Júlio Beutler

ORCID: https://orcid.org/0000-0002-1963-4148 Federal Rural University of Rio de Janeiro, Brazil E-mail: s.parana@yahoo.com.br

Orlando Carlos Huertas Tavares

ORCID: http://orcid.org/0000-0001-9581-0994 Federal Rural University of Rio de Janeiro, Brazil E-mail: ochtavares@gmail.com

Andrés Calderín Garcia

ORCID: http://orcid.org/0000-0001-5963-3847 Federal Rural University of Rio de Janeiro, Brazil E-mail: cg.andres@gmail.com

Marcos Gervasio Pereira

ORCID: https://orcid.org/0000-0002-1402-3612 Federal Rural University of Rio de Janeiro, Brazil E-mail: mgervasiopereira01@gmail.com
\end{abstract}

\begin{abstract}
Urban trees positively influence the quality of life in cities, but they need to be pruned regularly, generating a large amount of solid urban waste. This study aimed to compost urban pruning waste, evaluate its physical, chemical, structural characteristics, and determine its potential as a substrate to produce forest seedlings. The pruning residue was obtained from the Rio de Janeiro Municipal Cleaning Company (COMLURB) - Brazil. Twigs and leaves $\leq 8 \mathrm{~cm}$ in diameter were chopped and arranged on a trapezoidal windrow. Temperature, humidity, and aeration were controlled throughout the composting process. Irrigation and turning were carried out as needed. The composting process took 122 days. The compost was dried, processed, and evaluated for physical and chemical characteristics. The leachate was collected and characterized by ${ }^{13} \mathrm{C}$ CP MAS NMR. The temperature patterns were consistent with the thermophilic, mesophilic, and maturation stages. Part of the chemical and physical characteristics of the compound was classified as adequate, according to the literature. The leachate contained large amounts of $\mathrm{C}$ alkyl and low amounts of $\mathrm{C}$ carbonyl at all times of composting. The characteristics determined indicated that the composting process was interrupted before complete maturation was achieved. However, the compound can be combined with other materials to produce a complete substrate.
\end{abstract}

Keywords: Composting; Substrate; Urban solid waste; NMR; Physical characteristics, Chemical characteristics.

\section{Resumo}

A arborização urbana assume vital importância nos grandes centros urbanos, sendo necessária para melhoria da qualidade de vida nas cidades. Entretanto, para evitar danos a patrimônios, redes de distribuição de energia e água, é fundamental a manutenção da arborização através de podas periódicas, as quais geram resíduos sólidos urbanos verdes. Diante do exposto, esse estudo teve por objetivo avaliar o processo de compostagem dos resíduos da poda urbana, visando aproveitamento de baixo custo, e as características físicas e químicas do composto gerado para utilização como substrato na produção de mudas florestais. O resíduo de poda foi cedido pela Companhia Municipal de Limpeza Urbana (COMLURB). Após o recebimento do material, o mesmo foi triado em galhos finos $(<8 \mathrm{~cm})$ e folhas; triturado em picador; e dispostos em leira com formato piramidal. Posteriormente a montagem da leira teve início o controle do processo de compostagem, sendo realizado o monitoramento da temperatura, umidade e aeração. Após o processo de revolvimento e maturação (122 dias), o material foi peneirado, seco em condições naturais e armazenado. Posteriormente, foram determinadas as características físicas (densidade - DS, porosidade total - PT, espaço de aeração - EA, microporosidade, água facilmente disponível - AFD, água tamponante - AT e água disponível - AD), e químicas $(\mathrm{pH}$, condutividade elétrica - CE, teor total de sais solúveis - TTSS, capacidade de troca catiônica - CTC, relação 
carbono/nitrogênio - $\mathrm{C} / \mathrm{N}$, nutrientes e metais pesados) no composto de resíduo de poda urbana (CP). Também foram coletadas oito amostras de lixiviados, produzidos nos primeiros 30 dias do processo de compostagem, em diferentes tempos $(0,4,8,11,15,19,22$ e 30 dias $)$ e caracterizadas por espectroscopia ( ${ }^{13} \mathrm{C}$ NMR CP MAS). Após 24 horas da montagem da leira, constatou-se a elevação significativa da temperatura, dando início ao processo de compostagem. Foram identificadas as fases termófila, mesófila e de maturação ao decorrer do processo. Os valores encontrados para DS, PT, EA, pH, CE, TTSS, CTC e metais pesados foram classificados como adequados segundo a literatura e a legislação; em contrapartida, microposidade, AFD, AT, AD, relação C/N e a maioria dos nutrientes classificados como inadequados. Independentemente do tempo de compostagem é possível observar predominância de estruturas do tipo Calk-(A,R) e baixas quantidades de estruturas do tipo $\mathrm{CC}=\mathrm{O}$ nos lixiviados. Diante dos resultados, infere-se que é adequado utilizar o processo de compostagem para aproveitamento do resíduo de poda urbana, sem a utilização de outras fontes orgânicas e/ou minerais, sendo necessário adaptações no processo; o CP apresentou características físicas e químicas que evidenciaram a interrupção do processo antes da maturação completa do composto, porém, algumas estão adequadas para utilização como componente na formulação de substratos.

Palavras-chave: Compostagem; Substrato; Resíduo sólido urbano; RMN; Características físicas; Características químicas.

\section{Resumen}

La forestación urbana adquiere una importancia vital en los grandes centros urbanos, siendo necesaria para mejorar la calidad de vida en las ciudades. Sin embargo, para evitar daños a los activos, redes de distribución de energía y agua, es fundamental mantener la forestación mediante podas periódicas, que generan residuos sólidos urbanos verdes. Dado lo anterior, este estudio tuvo como objetivo evaluar el proceso de compostaje de residuos de poda urbana, con el objetivo de un uso de bajo costo, y las características físicas y químicas del compost generado para su uso como sustrato en la producción de plántulas forestales. Los residuos de poda fueron proporcionados por la Empresa Municipal de Limpieza (COMLURB). Después de recibir el material, se clasificó en ramas delgadas $(<8 \mathrm{~cm})$ y hojas; triturado en astilladora; y dispuestos en una pila con forma piramidal. Posteriormente, se comenzó con el ensamblaje de la pila para controlar el proceso de compostaje, seguido del monitoreo de temperatura, humedad y aireación. Después del proceso de volteo y maduración (122 días), el material se tamizó, se secó en condiciones naturales y se almacenó. Posteriormente, las características físicas (densidad - DS, porosidad total - PT, espacio de aireación - EA, microporosidad, agua fácilmente disponible - AFD, agua amortiguadora - AT y agua disponible - AD) y químicas (potencial de hidrógeno - $\mathrm{pH}$, conductividad eléctrica - CE, contenido total de sales solubles - TTSS, capacidad de intercambio catiónico - CTC, relación carbono / nitrógeno - $\mathrm{C} / \mathrm{N}$, nutrientes y metales pesados) en los residuos de poda urbana $(\mathrm{CP})$. También se recolectaron ocho muestras de lixiviados, producidos en los primeros 30 días del proceso de compostaje, en diferentes momentos $\left(0,4,8,11,15,19,22\right.$ y 30 días) y caracterizados por espectroscopía $\left({ }^{13} \mathrm{C}\right.$ NMR CP MAS $)$. Luego de 24 horas de ensamblar la pila, se observó un aumento significativo de temperatura, iniciando el proceso de compostaje. Durante el proceso se identificaron las fases termofílica, mesofílica y de maduración. Los valores encontrados para DS, PT, EA, pH, CE, TTSS, CTC y metales pesados se clasificaron como adecuados de acuerdo con la literatura y la legislación; en contraste, micropositividad, AFD, AT, AD, relación C / N y la mayoría de los nutrientes clasificados como inadecuados. Independientemente del tiempo de compostaje, es posible observar un predominio de estructuras del tipo Calk- (A, R) y bajas cantidades de estructuras del tipo $\mathrm{CC}=\mathrm{O}$ en el lixiviado. A la vista de los resultados, parece oportuno utilizar el proceso de compostaje para aprovechar los residuos de la poda urbana, sin el uso de otras fuentes orgánicas y / o minerales, requiriendo adaptaciones en el proceso; el CP mostró características físicas y químicas que evidenciaron la interrupción del proceso antes de la maduración completa del compuesto, pero algunas aptas para su uso como componente en la formulación de sustratos.

Palabras clave: Compostaje; Sustrato; Residuos sólidos urbanos; RMN; Características físicas; Características químicas.

\section{Introduction}

The city of Rio de Janeiro, Brazil, as many other urban centers, generates large amounts of organic residues that have the potential to be used for the production of plant substrate. Urban solid waste, a large proportion of which is green waste (Martins et al., 2011), is commonly incinerated or buried in landfills (Lim et al., 2016). These disposal methods are not environmentally friendly and have been linked with diverse socio-environmental and economic problems in society, mainly those related to public health, water resources, and atmospheric pollution (Santos Filho et al., 2018). Stabilization of organic matter should be carried out through controlled biological processes (Baratta Junior et al., 2010), such as composting. This ancient practice is an effective, sustainable, and low-cost alternative for reusing urban pruning waste and can be managed to accelerate the decomposition of organic matter (Oliveira et al., 2008). Key process parameters include temperature, aeration rate, moisture content, $\mathrm{pH}$, carbon (C)/nitrogen (N) ratio, particle size, and microbial activity (Valente et al., 2009). 
In addition to minimizing environmental impacts on soil, air, and water, composting affords a nutrient-rich organic substrate that promotes seedling growth (Santos et al., 2015). In recent years, there has been an increasing demand for organic substrates and fertilizers. The substrate can directly influence seedling quality, and, consequently, the establishment and growth of trees (Santos and Castilho 2016; Kratz et al., 2013). A high-quality substrate has good physical properties, such as density, total porosity, surface area, and field capacity (Schäfer et al., 2015), and good chemical attributes, including pH, cation-exchange capacity (CEC), electrical conductivity, total soluble salts (TSS), and macro- and micronutrient contents (Fermino, 2003; Kämpf, 2000).

This study aimed to compost urban pruning waste and determine the potential of organic compost as a substrate for seedling production by evaluating its physical, chemical, and structural characteristics.

\section{Methodology}

Urban pruning waste was composted and analyzed for physical, chemical, and structural properties.

\section{Composting process}

The experiment was conducted in a non-heated, plastic-covered greenhouse from December 2017 to April 2018. The pruning waste was provided by the Municipal Cleaning Company (COMLURB) and obtained from the Waste Transfer Station of the Caju neighborhood in Rio de Janeiro, Brazil, which receives municipal solid waste, mainly street and household refuse. The maximum average temperatures were $25-26{ }^{\circ} \mathrm{C}$, according to data from a weather station in Seropédica, Rio de Janeiro, Brazil, and inside the greenhouse was $30^{\circ} \mathrm{C}$, based on data logger equipment analysis.

Plant residues were mechanically sorted by size, and branches exceeding $8.00 \mathrm{~cm}$ in diameter were discarded. The material was shredded with a 13.5 HP gasoline-powered shredder (ES 550G, Trapp Ltd., Jaraguá do Sul, Santa Catarina, Brazil) to increase the surface area available for microbial action. In total, $400 \mathrm{~kg}$ of shredded waste was obtained. Waste composition varied according to the availability of pruned material. The predominant plant species were Albizia lebbeck (L.) Benth., Ficus benjamina L., Leucaena leucocephala (Lam.) de Wit, Licania tomentosa (Benth.) Fritsch, Mangifera indica L., and Terminalia catappa L.

A small-scale, aerobic composting process was used. Shredded pruning waste was arranged in a $1.52 \mathrm{~m} \mathrm{long}, 1.20 \mathrm{~m}$ wide (base), and $1.02 \mathrm{~m}$ high trapezoid windrow on a waterproof pad. The pile was placed on a straight and slightly sloping surface so as to facilitate leachate collection and prevent the accumulation of liquids at the bottom. Compost starters, accelerators, or other sources of organic residues were not added. Shortly after mounting, the windrow was watered to promote microbial activity and heat production (Kiehl, 2004; Pereira Neto, 2007).

Temperature was monitored daily, in the early morning or late afternoon, during the first 90 days of composting. Windrow temperature stabilized at 90 days and was not recorded thereafter. Temperature was measured to the nearest $1{ }^{\circ} \mathrm{C}$ using a digital thermometer (Incoterm, Porto Alegre, Rio Grande do Sul, Brazil) attached to a $1.20 \mathrm{~m}$ long wooden support inserted in the central bottom, middle, and top portions of the windrow.

Manual aeration (turning) was performed as needed. Temperature, odors, and overall visual appearance were used to determine the need for water application. The ideal moisture content range for microbial activity and thermal stability was considered to be between 40 and $60 \%$ (Kiehl 1985). Because the windrow reached high temperatures in the first $72 \mathrm{~h}$, the frequency of turning and irrigation was set at twice a week for the first 8 weeks (56 days). After this period, the windrow was turned twice a month.

Leachate was collected into plastic containers at every turning (days $0,4,8,11,15,19,22$, and 30), totaling 8 collections. Samples were homogenized, aliquoted, immediately frozen, and freeze dried. 
The composting process lasted 122 days. Upon completion, compost was spread evenly onto a surface and turned every two days until dry. Samples were sieved through an $8 \mathrm{~mm}$ screen, ground in a cutting mill, and sieved to obtain particles ranging from 4 to $6 \mathrm{~mm}$ in diameter. Samples were stored in raffia bags in a dry place at room temperature until use.

\section{Structural characterization of compost leachate}

Leachate was analyzed by ${ }^{13} \mathrm{C}$ cross-polarization magic-angle spinning nuclear magnetic resonance (CP/MAS NMR) using a Bruker Avance II $400 \mathrm{MHz}$ NMR spectrometer equipped with a $4 \mathrm{~mm}$ MAS probe operating at $100.163 \mathrm{MHz}$. Zirconium dioxide $\left(\mathrm{ZrO}_{2}\right)$ rotors were packed with freeze-dried leachate, sealed with Kel-F caps, and spun at $8 \pm 1 \mathrm{kHz}$. A total of 2048 data points and scans were collected using an acquisition time of $34 \mathrm{~ms}$, a recycle delay of $5 \mathrm{~s}$, and a contact time of $2 \mathrm{~ms}$. Spectral data were processed using Bruker Topspin version 2.1. Free induction decays were transformed using zero-filling to 4 $\mathrm{k}$ with a line broadening of 70 .

\section{Physical and chemical characterization of pruning waste compost}

Pruning waste compost was evaluated for moisture content, density, and water-holding capacity (WHC) according to Normative Instruction no. 17/2007, which defines the official methods for analysis of plant substrates in Brazil (MAPA, 2007). Total porosity, macroporosity, microporosity, readily available water (RAW), available water (AW), and residual water (RW) contents were determined from tension tables and water retention curves at 0, 10, 50, and $78 \mathrm{hPa}$, as adapted from Kiehl (1979).

Particle size distribution was determined by sieving $100 \mathrm{~g}$ of air-dried compost through 4.00, 1.00, 0.53, and $0.106 \mathrm{~mm}$ sieves for 3 min using a mechanical stirrer, as adapted from Fermino (2003). Results are the mean of three determinations and are expressed in percent weight relative to the total weight of the sample. Particles were classified as very large $(>3.35 \mathrm{~mm})$, large $(2.00<\mathrm{x} \leq 3.35 \mathrm{~mm})$, intermediate $(0.50<\mathrm{x} \leq 2.00 \mathrm{~mm})$, fine $(0.10<\mathrm{x} \leq 0.50 \mathrm{~mm})$ and very fine $(\leq 0.10 \mathrm{~mm})$ (Zorzeto et al., 2014).

Electrical conductivity, $\mathrm{pH}$ in water $(1: 5 \mathrm{v} / \mathrm{v})$, and CEC were determined in triplicate according to Normative Instruction no. 17/2007 (MAPA, 2007). TSS content was determined by the method of Röber and Schaller (1985). Chromium (Cr), lead $(\mathrm{Pb})$, zinc $(\mathrm{Zn})$, cadmium $(\mathrm{Cd})$, and nickel $(\mathrm{Ni})$ contents were analyzed by atomic absorption spectrometry after nitric/perchloric acid digestion (Sarruge and Haag, 1974). For determination of C and N contents, $250 \mathrm{mg}$ of sample was ground in a porcelain mortar and sieved through a 100-mesh sieve. The retained material was analyzed at $900^{\circ} \mathrm{C}$ using a Carlo Erba EA-1110 elemental analyzer (Milan, Italy). Available phosphorus $(\mathrm{P})$, potassium $\left(\mathrm{K}^{+}\right)$, sodium $\left(\mathrm{Na}^{2+}\right)$, calcium $\left(\mathrm{Ca}^{2+}\right)$, and magnesium $\left(\mathrm{Mg}^{2+}\right)$ were determined according to Teixeira et al. (2017).

Data were subjected to descriptive analysis, and the results are presented as mean and standard error.

\section{Results and Discussion}

\section{Composting process}

Figure 1 shows the weekly variation in windrow temperature during the first 84 days ( 12 weeks). The mean temperature was $31 \pm 3{ }^{\circ} \mathrm{C}$. Temperatures reached $50-60{ }^{\circ} \mathrm{C}$ at the beginning of the process (thermophilic stage), decreasing significantly from day 12 onward. The windrow reached temperatures close to the ambient temperature at around day 63, indicating the beginning of the maturation stage. However, according to the literature (Valente et al., 2009; Pereira Neto, 2007), a compost heap should maintain thermophilic temperatures for a minimum of 30 days. 
Figure 1. Maximum and minimum ambient temperatures and mean windrow temperatures during the first 84 days of composting (2 December 2017 to 24 February 2018). Values are the mean of two weekly measurements.

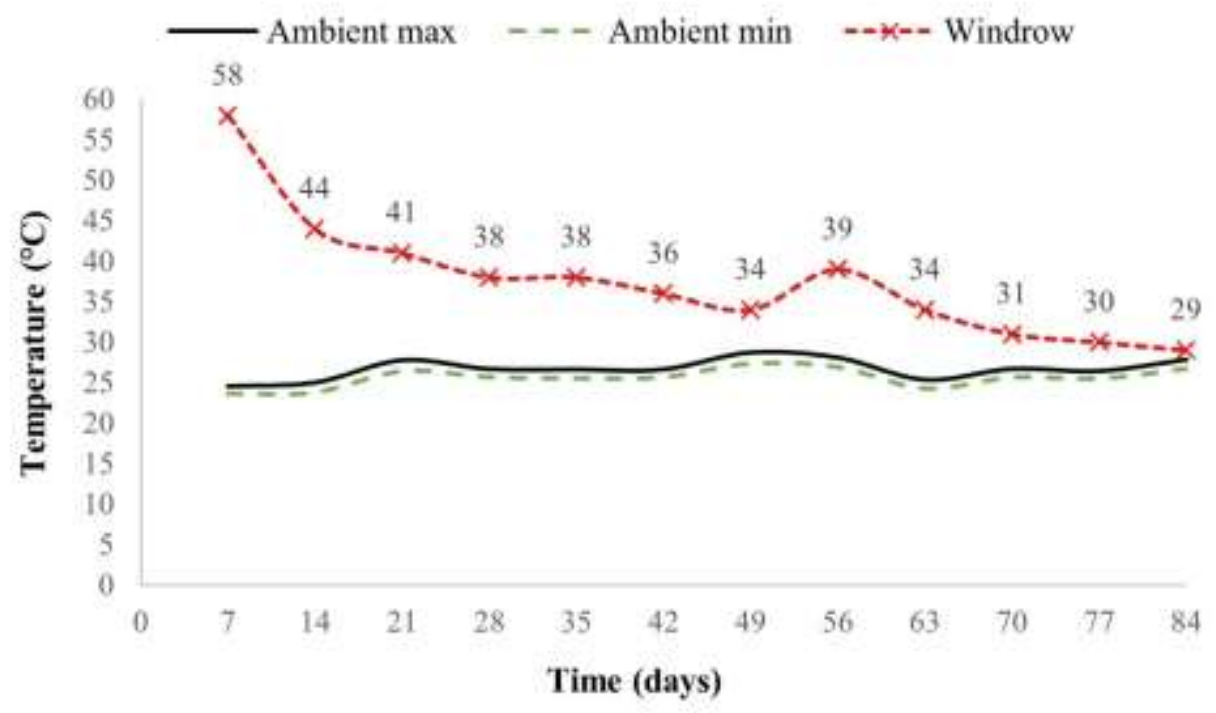

Source: Authors.

Temperature is one of the most important control parameters in composting (Rocha et al., 2015; Cotta et al., 2015; Valente et al., 2009; Pereira Neto, 2007), as it is a low-cost and reliable indicator of composting stage (Santos et al., 2015). At the beginning of composting, the windrow must reach thermophilic temperatures $\left(45-65{ }^{\circ} \mathrm{C}\right)$ within 12 to $24 \mathrm{~h}$, characterizing the heating phase (first phase). Temperatures must remain constant throughout the second phase (lasting about 80 days) and decrease to below $45^{\circ} \mathrm{C}$ only at the end of the second phase and beginning of the third phase (cooling phase). The fourth and final stage of composting begins when temperatures stabilize below $40{ }^{\circ} \mathrm{C}$ (mesophilic temperatures) (Pereira Neto, 2007).

Moisture content is another important control parameter (Valente et al., 2009; Pereira Neto, 2007). In this study, moisture content was monitored visually and increased with irrigation, when necessary. Water is essential for microbial activity (Pereira Neto, 2007). Because urban pruning waste has a low moisture content (about 44\%), it requires irrigation to reach the ideal level for composting (55\%) (Reis, 2005). There was a significant loss of water in the early stages of composting because of the high temperatures, necessitating a high supply of water. As composting progressed, the water retention capacity of the material increased, making it possible to reduce the frequency of irrigation.

Cotta et al. (2015), in assessing the composting and vermicomposting of plant waste, bovine manure, and sawdust, observed a similar temperature pattern to that found in the present study. The compost heap reached a maximum temperature of $35^{\circ} \mathrm{C}$ on the 14 th day. The authors expected higher temperatures $\left(70{ }^{\circ} \mathrm{C}\right)$ and attributed the observed values to the low amount of waste used. Temperature stabilized at $25^{\circ} \mathrm{C}$ after the 56th day of composting. According to the authors, temperature is greatly affected by substrate moisture content, nutrient availability, and windrow size.

\section{${ }^{13} \mathrm{C}$ CP/MAS NMR characterization of compost leachate}

${ }^{13} \mathrm{C}$ CP/MAS NMR spectra of leachate collected at different composting periods are shown in Figure 2. Note that all spectra showed patterns of humified compounds. Peaks at 19, 20, 30, 39 ppm are characteristic of $-\mathrm{CH}_{3}$ and $-\mathrm{CH}_{2}$ aliphatic groups in polypeptides and lipids. The presence of a methoxy $\mathrm{C}\left(-\mathrm{OCH}_{3}\right)$ and a carbon atom in polypeptides $(\mathrm{R}-\mathrm{C}=-* \mathrm{CH}-\mathrm{NH})$ can be identified by signals at about $55 \mathrm{ppm}$. The presence of $-\mathrm{C}-\mathrm{OH}$ groups, characteristic of cellulose and hemicellulose fragments, is indicated by signals at $\sim 73 \mathrm{ppm}$. Carbohydrate and lignin-like structures were also identified, as evidenced by 
signals at around 104 ppm, corresponding to anomeric C (di-O-alkyl C) and C-2 in guaiacyl and syringyl fragments, respectively. Aromatic groups with a low functionalization degree were identified by signals at $\sim 115,131$, and 133 ppm, characteristic of C1 in guaiacyl and syringyl fragments. $(\mathrm{O}, \mathrm{N})$-aryl C groups were identified by signals at about 149, 150, and 152 ppm. The intense signal at $\sim 175 \mathrm{ppm}$ indicated that compost leachate contained carboxylic and ester compounds of plant and microbial origin. The signal at about 200 ppm indicates the presence of carbonyl C (Deshmukh et al., 2005; Johnson et al., 2005; Baldock \& Smernik 2002; Inbar et al., 1990).

Figure 2. ${ }^{13} \mathrm{C} \mathrm{CP/MAS} \mathrm{NMR} \mathrm{spectra} \mathrm{of} \mathrm{compost} \mathrm{leachates} \mathrm{collected} \mathrm{in} \mathrm{the} \mathrm{first} 30$ days of composting.
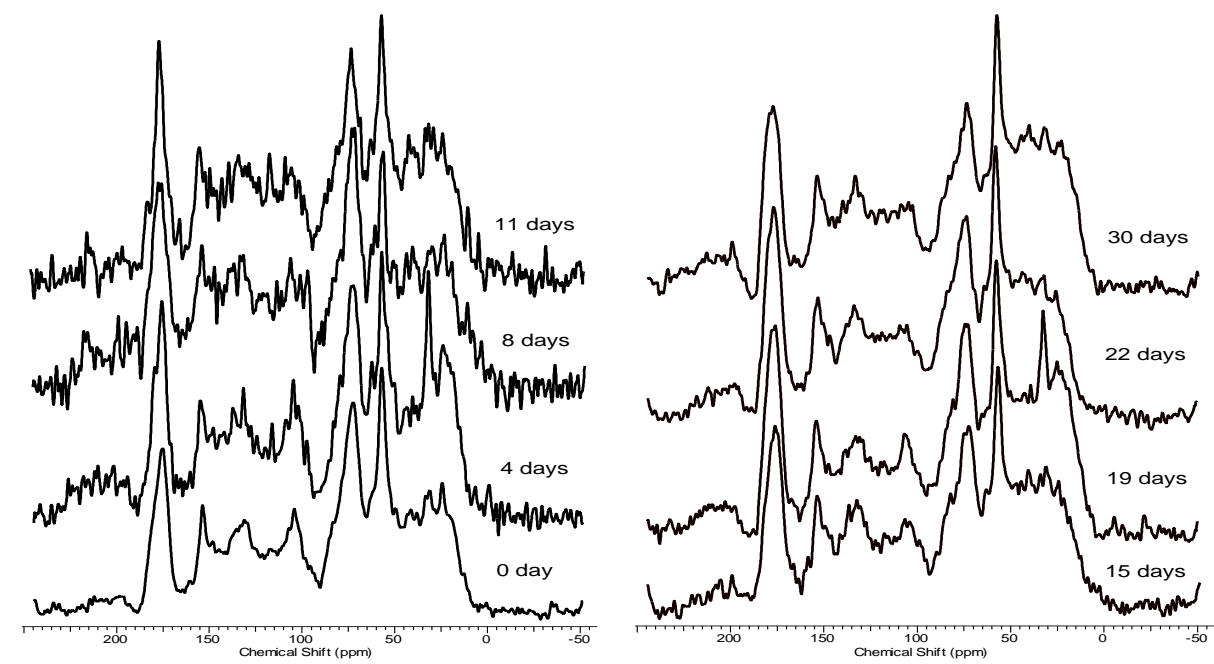

Source: Authors.

The relative distribution of organic $\mathrm{C}$ in compost leachate is shown in Figure 3. $\mathrm{C}$ structure varied greatly with composting time. Non-functionalized aliphatic compounds (alkyl C) predominated throughout the composting period. The content of $(\mathrm{O}, \mathrm{N})$-alkyl $\mathrm{C}$ decreased in the first days of composting (4-8 days) but remained constant thereafter. Similar behavior was observed for methoxy C (O-alkyl C). Di-O-alkyl-C content, which indicates the presence of carbohydrates, decreased gradually with time. The content of non-functionalized (aryl C) and functionalized $[(\mathrm{O}, \mathrm{N})$-aryl $\mathrm{C}]$ aromatic groups increased during the first 11 days of composting and then remained constant. Carboxyl $\mathrm{C}(-\mathrm{COOH})$ content varied little with composting time, and carbonyl $\mathrm{C}(\mathrm{C}=\mathrm{O})$ content decreased from the beginning of composting until day 15, increasing thereafter. 
Figure 3. A) Relative carbon distribution determined by integration of ${ }^{13} \mathrm{C} C P / M A S$ NMR spectra of compost leachates collected in the first 30 days of composting. B) Relative abundance of aromatic and aliphatic compounds.
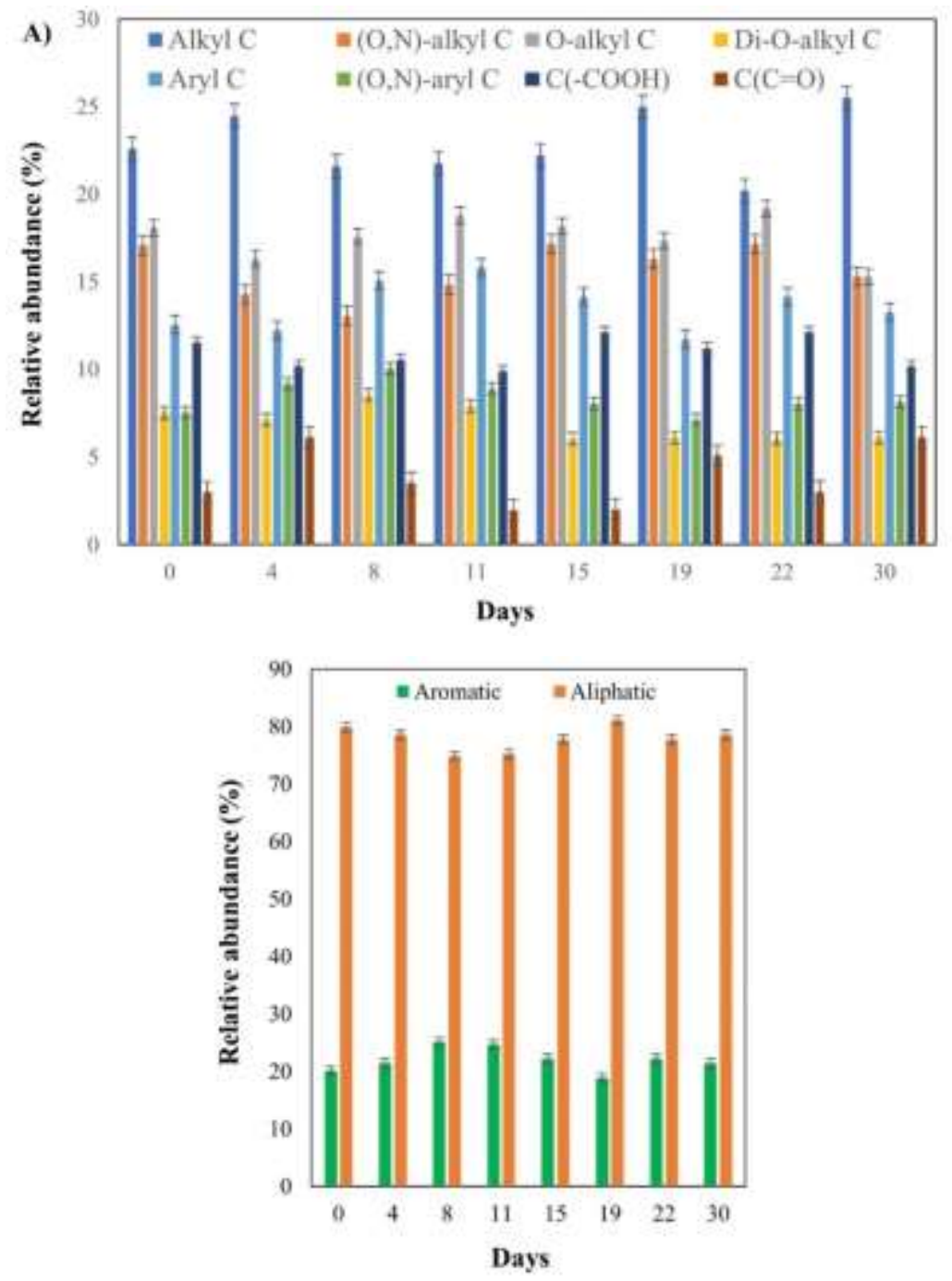

Source: Authors.

Changes in the proportion of aliphatic and aromatic groups reflect the structural changes in leachate resulting from the composting process. A decrease in aliphaticity and a consequent increase in aromaticity were observed between days 8 and 11 . This pattern indicates that more recalcitrant compounds remained unchanged, whereas labile compounds were transformed. Structural changes were more intense during the first 11 days of composting.

The degree of humification can be estimated from the aromaticity of organic matter fractions in soil. The higher the aromaticity, the greater the humification degree (Kavdir et al., 2005). However, this relationship is more accurate when recalcitrant compounds, such as lignin and tannin, are taken into account, as they also contain aromatic groups (Rossi, 2013). The low aromaticity of compost leachate can be attributed to the short composting period. The results suggest that more aromatic compounds require a longer composting time to be degraded.

Aguiar et al. (2012) reported similar ${ }^{13} \mathrm{C}$ NMR patterns to those found in this study. In the referred study, alkyl C (0-45 ppm) and O-alkyl C (45-110 ppm) accounted for 69-78\% of the carbon content in vermicomposts. Souza et al. (2019) investigated changes in organic matter structure and heavy metal solubility in poultry litter during composting and observed a predominance of more labile structures. The authors found that the initial phase of composting was characterized by a 
predominance of hydrogen linked to hydrophilic aliphatic C; during the thermophilic phase, the intensity of these signals decreased, and that of hydrogen bound to recalcitrant and hydrophobic aliphatic $\mathrm{C}$ increased. Therefore, at later stages of composting, there was a marked presence of phenols derived from lignin and microbial carbohydrates.

\section{Physical characteristics of urban pruning waste compost}

The physical properties of a plant substrate are extremely important because, after the substrate is applied to the soil or to pots, its physical parameters cannot be modified. In contrast, chemical properties can be altered through fertilization, irrigation, or both (fertigation) (Abreu et al., 2017; Kratz et al., 2013).

Pruning waste compost had a density of $0.35 \mathrm{~g} \mathrm{~cm}^{-3}$ (Table 1), classified as moderate $\left(0.25-0.50 \mathrm{~g} \mathrm{~cm}^{-3}\right)$ according to the substrate quality criteria proposed by Gonçalves and Poggiani (1996). According to the authors, the adequate density range is 0.45 to $0.55 \mathrm{~g} \mathrm{~cm}^{-3}$. Delarmelina et al. (2014) assessed the suitability of sewage sludge, vermiculite, and rice husk in different proportions as substrate for Sesbania virgata seedlings. A commercial substrate and the substrate composed of $80 \%$ sewage sludge and $20 \%$ vermiculite were found to have moderate densities, whereas the other 12 substrates had low densities $(<0.25 \mathrm{~g}$ $\left.\mathrm{cm}^{-3}\right)$.

Table 1. Physical characteristics of organic compost.

\begin{tabular}{ccc}
\hline Parameter & Value & Classification $^{\mathrm{a}}$ \\
\hline Density & $0.35 \mathrm{~g} \mathrm{~cm}^{-3}$ & moderate \\
Total porosity & $87 \%$ & high \\
Macroporosity & $32 \%$ & moderate \\
Microporosity & $60 \%$ & high \\
Readily available water & $8 \%$ & low \\
Residual water & $1 \%$ & low \\
Available water & $0.08 \mathrm{~m}^{3} \mathrm{~m}^{-3}$ & low \\
WHC at $0 \mathrm{hPa}$ & $0.87 \mathrm{~m}^{3} \mathrm{~m}^{-3}$ & adequate \\
WHC at $10 \mathrm{hPa}$ & $0.55 \mathrm{~m}^{3} \mathrm{~m}^{-3}$ & adequate \\
WHC at $50 \mathrm{hPa}$ & $0.47 \mathrm{~m}^{3} \mathrm{~m}^{-3}$ & adequate \\
WHC at $78 \mathrm{hPa}$ & $0.48 \mathrm{~m}^{3} \mathrm{~m}^{-3}$ & low \\
Particle size & $97.14 \%$ & moderate \\
\hline
\end{tabular}

WHC, water holding capacity.

aPhysical properties were classified according to criteria proposed by Zorzeto et al. (2014); Gonçalves and Poggiani (1996) for assessment of plant substrate quality. Source: Authors.

The total porosity of the compost was high (87\%) (Table 1) but close to adequate (75-85\%). Adequate porosity contributes to aeration, water filtration, and drainage (Costa et al., 2017). To better understand the results of total porosity, it is necessary to analyze soil macro- and microporosity and correlate them with the proportion of pores occupied by water and air (Abreu et al., 2017). Compost had a macroporosity of 32\% (Table 1), considered moderate (20-40\%), and a microporosity of $60 \%$, which is high but close to adequate (45-55\%) (Table 1). The high WHC of compost can be attributed to its high microporosity; and the moderate aeration and drainage capacity, to the moderate macroporosity. Schäfer et al. (2015) highlighted 
that soil macroporosity and WHC directly influence the irrigation requirements of crops.

RAW content, determined at 10 to $50 \mathrm{hPa}$, accounted for the major part of $\mathrm{AW}$, as there was practically no difference between the amount of water released under 50 and $78 \mathrm{hPa}$. Costa et al. (2017) reported that low values of RAW and AW in substrates rich in organic matter indicate a high proportion of micropores, which promote water adsorption. Kratz et al. (2013), in studying the physical and chemical properties of renewable substrates, observed that soils with large particles have low AW content as a result of rapid drainage and, therefore, require a higher frequency of irrigation.

High WHC values were observed at all pressures, as shown in Table 1. We emphasize that the higher the volume of available water at lower tensions, the less energy plants will need to expend to absorb water (Zorzeto, 2011). High WHC at 10 and $50 \mathrm{hPa}$ indicates a good water storage capacity. However, a more important property is the ability of soil to release sufficient amounts of water for plants. The amount of available water at $78 \mathrm{hPa}$ was considered low and was lower than that retained at this pressure, indicating that pruning waste compost requires frequent irrigation.

Particle size distribution is an important factor affecting soil physical quality. A wide distribution of particle size indicates that small particles may become lodged in void spaces between large particles, reducing pore size and, consequently, total porosity. As a result, microporosity, compaction, and WHC increase. The compost had a narrow distribution of particles: $0.16 \%$ were classified as very large, $47.26 \%$ as large, $49.88 \%$ as intermediate, and $0.18 \%$ as fine. About $2.04 \%$ of the material was not retained in any sieve and $0.48 \%$ was lost during processing.

The predominance of intermediate-sized particles in substrates, combined with high total porosity and presence of micropores, favors seedling development, as these characteristics promote good aeration and water retention. However, as Fermino (2003) emphasized, care must be taken when analyzing the particle size distribution of substrates, as substrates are mainly composed of partially decomposed organic materials with irregular shapes.

Compost $\mathrm{pH}$ varied from 6.24 to 6.74 throughout the composting process, with a mean of 6.56 (Table 2).

Table 2. Chemical characteristics of organic compost.

\begin{tabular}{ccc}
\hline Parameter & Value & Classification $^{\text {a }}$ \\
\hline pH in water & 6.6 & low \\
Electrical conductivity & $0.78 \mathrm{dS} \mathrm{m}^{-1}$ & low \\
Total soluble salts & $1.52 \mathrm{~kg} \mathrm{~m}^{-3}$ & moderate \\
Cation-exchange capacity & $288.29 \mathrm{mmol}_{\mathrm{c}} \mathrm{dm}^{-3}$ & adequate \\
C/N ratio & $22: 1$ & high \\
Total N & $1 \%$ & low \\
Total C & $22 \%$ & high \\
Available P & $87.09 \mathrm{mg} \mathrm{dm}^{-3}$ & low \\
Exchangeable $\mathrm{K}$ & $0.93 \mathrm{cmol}_{\mathrm{c} \mathrm{dm}}^{-3}$ & adequate \\
Exchangeable C & $15.3 \mathrm{cmolc} \mathrm{dm}^{-3}$ & low \\
Exchangeable Mg & $4 \mathrm{cmol}_{\mathrm{c} \mathrm{dm}}^{-3}$ & low \\
Exchangeable $\mathrm{Na}$ & $0.26 \mathrm{cmol}_{\mathrm{c} \mathrm{dm}}^{-3}$ & adequate \\
$\mathrm{Cd}$ & $0.983 \mathrm{mg} \mathrm{kg}^{-1}$ & adequate \\
$\mathrm{Zn}$ & $29.317 \mathrm{mg} \mathrm{kg}^{-1}$ & adequate \\
$\mathrm{Pb}$ & $0 \mathrm{mg} \mathrm{kg}^{-1}$ & adequate \\
$\mathrm{Ni}$ & $0.233 \mathrm{mg} \mathrm{kg}^{-1}$ & adequate \\
$\mathrm{Cr}$ & $0.48 \mathrm{mg} \mathrm{kg}^{-1}$ &
\end{tabular}

${ }^{a}$ Chemical properties were classified according to criteria proposed by Neto et al. (2009); Gonçalves and Poggiani (1996) for assessment of plant substrate quality. Source: Authors. 
The beginning of composting is characterized by the formation of mineral acids and carbon dioxide, which increase acidity ( $\mathrm{pH}$ 5.0-6.0). These compounds are replaced by organic acids that react with bases released from organic matter decomposition and carbon dioxide elimination, increasing alkalinity (pH 8-8.5) (Valente et al., 2009; Pereira Neto, 2007). Mature compost has a pH of 7-8 (Burle et al., 2018).

The final $\mathrm{pH}$ (6.6) was close to that considered adequate (5.5-6.5) by Gonçalves and Poggiani (1996). Normative Instruction $\mathrm{N}^{\mathrm{o}}$. 25/2009 (MAPA 2009) defines that the minimum $\mathrm{pH}$ for organic compost is 6.0. Therefore, the organic compost was within the limit established by legislation but did not reach the $\mathrm{pH}$ indicative of compost maturity.

Araújo Neto et al. (2009) proposed a classification system for the electrical conductivity of substrates: high $(2.0<\mathrm{x} \leq$ $\left.4.0 \mathrm{dS} \mathrm{m}^{-1}\right)$, moderate $\left(1.0<\mathrm{x} \leq 2.0 \mathrm{dS} \mathrm{m}^{-1}\right)$, and low $\left(\leq 1.0 \mathrm{dS} \mathrm{m}^{-1}\right)$. The electrical conductivity of pruning waste compost was low, $0.78 \mathrm{dS} \mathrm{m}^{-1}$, which demonstrates that the compost presents no risk for use as a substrate (Brito et al., 2017).

In soils, salinity is a determinant of electrical conductivity; in substrates, however, salinity is commonly expressed as TSS (Fermino, 2003). According to criteria established by Kämpf (2000), the TSS of pruning waste compost was in the intermediate range (1.0-2.0 $\mathrm{kg} \mathrm{m}^{-3}$ ) (Table 2). Excessive TSS can be harmful to some plant species. High sodium and chlorine concentrations in soil can promote changes of ionic, osmotic, nutritional, and hormonal nature in plants. Low electrical conductivity or TSS, on the other hand, can be indicative of low available nutrient content (Castro, 2018; Sá et al., 2015).

CEC expresses the capacity of the soil or substrate to hold cations at natural soil pH (Schmitz et al., 2002). Chemical analyses revealed the CEC of pruning waste compost to be $288.19 \mathrm{mmol}_{\mathrm{c}} \mathrm{dm}^{-3}$ (Table 2), which, according to Gonçalves and Poggiani (1996), is adequate (>200 $\left.\mathrm{mmol}_{\mathrm{c}} \mathrm{dm}^{-3}\right)$.

The $\mathrm{C} / \mathrm{N}$ ratio is an essential parameter for assessing both the composting process and the final substrate. It is an indicator of compost maturity and the humification degree of organic substances at the end of the process (Ros et al., 2015; Rocha et al., 2015; Valente et al., 2009). Humified substrates have a C/N ratio of 8:1 to 12:1 and semi-mature (or biostabilized) substrates have ratios of 13:1 to 18:1. Higher $\mathrm{C} / \mathrm{N}$ ratios may affect plant growth. The $\mathrm{C} / \mathrm{N}$ ratio of pruning waste compost was 22:1 (Table 2), well above the value considered adequate. According to Brazilian legislation (MAPA, 2009), the C/N ratio of organic compost cannot exceed 20 and the total $\mathrm{N}$ content must be at least $5.0 \mathrm{~g} \mathrm{~kg}^{-1}$. The results show that the compost was deficient in N content. Jiménez and Garcia (1989) argued that, because of the great variability in organic compost composition, it is not possible to affirm that a biostabilized compost has a $\mathrm{C} / \mathrm{N}$ ratio between 10:1 and 20:1. The authors suggested dividing the final $\mathrm{C} / \mathrm{N}$ ratio by the initial $\mathrm{C} / \mathrm{N}$ ratio. Values lower than 0.70 for composts aged more than 120 days indicate a satisfactory degradation.

Abreu et al. (2017), in assessing the potential of substrates formulated with biosolids for Schinus terebinthifolius Raddi and Handroanthus heptaphylus (Vell.) seedling production, found that commercial substrate (Mecplant@) had a high $\mathrm{C} / \mathrm{N}$ ratio (24:1). The authors argued that the result was due to high microbial activity. Microorganisms compete with seedlings for nutrients, mainly $\mathrm{N}$ and $\mathrm{S}$. Seedlings grown in substrates with high $\mathrm{C} / \mathrm{N}$ ratios may suffer from nutrient deficiency if proper fertilization is not carried out (Gonçalves and Poggiani 1996).

$\mathrm{N}$ and $\mathrm{Ca}$ contents were classified as adequate and $\mathrm{C}$ content as above the recommended (Table 2) (Gonçalves and Poggiani, 1996). The contents of the other nutrients were classified as low. It should be noted that the nutrient quality of pruning waste compost can be enhanced by adding another material rich in the deficient nutrients to obtain an adequate substrate. Severino et al. (2006) investigated the chemical composition of 11 organic materials used in substrates for seedling production. The authors found that sugarcane bagasse and sisal mucilage were low in nutrients and had high $\mathrm{C} / \mathrm{N}$ ratios. For some nutrients to become available to plants, organic material must be decomposed to a great extent. The authors concluded that none of the 11 materials could be used alone as a substrate, as they were deficient in at least one important nutrient.

In testing cattle manure, swine manure, and sugarcane bagasse as substrate for the production of guanandi seedlings, 
Vieira et al. (2014) observed that available N, Ca, and Cu levels could not be effectively increased by mixing organic wastes; in fact, the strategy led to an increase in the concentrations of potentially phytotoxic macronutrients. These findings show that care is needed when combining different organic wastes. Baratta Junior (2007), on the other hand, found that compost from urban pruning waste had adequate levels of nutrients for seedling production.

The heavy metal contents of pruning waste compost were well below the maximum limits established by Brazilian legislation (MAPA, 2009) (Cr, $500 \mathrm{mg} \mathrm{kg}{ }^{-1} ; \mathrm{Pb}, 300 \mathrm{mg} \mathrm{kg}{ }^{-1} ; \mathrm{Cd}, 8 \mathrm{mg} \mathrm{kg}^{-1}$; and Ni, $175 \mathrm{mg} \mathrm{kg}^{-1}$ ) and the United States Environmental Protection Agency.

\section{Conclusion}

Urban pruning waste was successfully composted using an aerobic process without other organic and/or mineral sources. The high aliphaticity and lack of change in aromaticity indicate that the compost was not mature after 122 days of composting. For the compost to achieve maturity, it is recommended to use larger amounts of waste (increasing windrow size) or reduce irrigation, facilitating temperature control.

The compost had adequate total porosity, microporosity, and $\mathrm{WHC}$ at 0,10 , and $50 \mathrm{hPa}$; moderate macroporosity and density; and low RAW, AW, RW, and WHC at $78 \mathrm{hPa}$. It had suitable pH, electrical conductivity, TSS, CEC, and heavy metal contents but inadequate nutrient contents and $\mathrm{C} / \mathrm{N}$ ratio. According to Brazilian legislation, the compost has adequate physicochemical properties to be used as a substrate component. A high-quality plant substrate can be obtained by adding another material rich in nutrients to pruning waste compost.

Due to the importance of afforestation in urban centers associated with the need to recycle organic waste and the production of seedlings, it is suggested that more research be carried out using pruning waste from urban afforestation for composting, adding more residues with high levels of nitrogen and new ones. ways to control the humidity of the material during the process.

\section{Acknowledgments}

This work was carried out with the support of the Coordination for the Improvement of Higher Education Personnel Brazil (CAPES) - Financing Code 001; and financed by the Pro-Management Association of Waters of the Paraíba do Sul River Basin (AGEVAP).

\section{References}

Abreu, A. H.-M., Leles, P. S. S., Melo, L. A., Oliveira, R. R., Ferreira, D. H. A. A. (2017). Caracterização e potencial de susbtratos formulados com biossólido na produção de mudas de Schinus terebinthifolius Raddi e Handroanthus heptaphyllus (Vell.) Mattos. Ciência Florestal, Santa Maria 27 (4): 1179 - 1190.

Araújo Neto, S. E., Azevedo, J. M. A., Galvão, R. O., Oliveira, E. B. L., Ferreira, R. L. F. (2009). Produção de muda orgânica de pimentão com diferentes substratos. Ciência Rural, Santa Maria 39 (5): 1408 - 1413.

Baldock, J. and Preston, C. M. (1992). Assessing the extent of decomposition of natural organic materials using solid state ${ }^{13}$ C NMR spectroscopy (1992) Australian Journal of Soil Research 35: 1061 - 1083.

Baratta Junior, A. P. (2007). Utilização do composto de resíduos da poda da arborização urbana em substratos para produção de mudas. 2007.62 f. Diss., Universidade Federal do Rio de Janeiro, Seropédica, RJ.

Baratta Junior, A. P., Magalhães, L. M. S. (2010). Aproveitamento de resíduos da poda de arvores do Rio de Janeiro para compostagem. Rev. Ciênc. AgroAmbientais 8 (1):113- 125 .

Burle, E. C., Andrade Neto, E. C., Santos, W. L. and Figueiredo, R. T. (2018). Compostagem em pequena escala de resíduos orgânicos com óleos e gorduras residuais - OGR. Ciências exatas e tecnológicas, Aracajú 4 (3): $11-20$.

Brito, L. P. S., Beckmann-Cavalcante, M. Z., Amaral, G. C., Silva, A. A., Avelino, R. C. (2017). Reutilização de resíduos regionais como substratos na produção de mudas de cultivares de alface a partir de sementes com e sem peletização. La Plata 116 (1): 51 - 61. 
Castro, R. S. (2018). Resíduos industriais como estimuladores da biodegradação de poda de árvores. Bacharelado, Universidade Tecnológica Federal do Paraná.

Costa, J. C. F., Mendonça, R. M. N., Fernandes, L. F., Oliveira, F. P., Santos, D. (2017). Caracterização física de substratos orgânicos para o enraizamento de estacas de goiabeira. $R B A S$, Viçosa 7 (2): $16-23$.

Cotta, J. A. O., Carvalho, N. L. C., Brum, T. S., Rezende, M. O. O. (2015). Compostagem versus vermicompostagem: comparação das técnicas utilizando resíduos vegetais, esterco bovina e serragem. Eng. Sanit. Ambient., 20 (1): $65-78$.

De Boodt M., Verdonck, O. and Cappaert, I. (1974). Method for measuring the water release curve of organic substrates. Acta Horticulturae, Wageningen, 37: $2054-2062$.

Delarmelina, W. M., Caldeira, M. V. W., Faria, J. C. T., Gonçalves, E. O., Rocha, R. L. F. (2014). Diferentes substratos para a produção de mudas de Sesbania virgata. Floresta e Ambiente, Seropédica 21 (2): 224 - 233.

Deshmukh, A. P., Simpson, A. J., Hadad, C. M., Hatcher, P. G. (2005). Insights into the structure of cutin and cutan from Agave americana leaf cuticle using HRMAS NMR spectroscopy. Organic Geochemistry 36: 1072 - 1085.

Fermino, M. H. (2003). Métodos de análise para caracterização física de substratos para plantas. Thesis, Universidade Federal do Rio Grande do Sul.

Gonçalves, J. L. M. and Poggiani, F. (1996). Substrato para produção de mudas florestais. Paper presented at the $13^{\text {th }}$ Solo-Suelo- Congresso Latino Americano de Ciência do Solo. Águas de Lindóia, São Paulo, Brasil.

Inbar, Y., Chen, Y. and Hadar, Y. (1990). Humic substances formed during the composting of organic matter. Soil Science Society of American Journal, 54: $1316-1323$.

Jiménez, E. I., Garcia, V. P. (1989). Evaluation of city refuse compost maturity: a review. Biological Wastes, Canary Islands, $27: 115$ - $142,1989$.

Johnson, C. E., Smernik, R. J., Siccama, T. G., Kiemle, D. K., Xu, Z., Vogt, D. J. (2005). Using ${ }^{13}$ C nuclear magnetic resonance spectroscopy for the study of northern hardwood tissues. Canadian Journal of Forest Research 35: 1821 - 1831.

Kavdir, Y., Ekinci, H., Yuksel, O., Mermut, A. R. (2005). Soil aggregate stability and ${ }^{13} \mathrm{C}$ CP/MAS-NMR assessment of organic matter in soils influenced by forest wildfires in Çanakkale, Turkey. Geoderma 129: 219-229.

Kämpf, A. N. (2000). Produção comercial de plantas ornamentais. 2rd ed. Guaíba: Agropecuária.

Kiehl, E. J. (1979). Manual de Edafologia: Relações Solo-Planta. São Paulo: Ceres.

Kiehl, E. J. (2004). Manual da Compostagem: maturação e qualidade do composto. Piracicaba: $4^{\mathrm{a}}$ ed. $173 \mathrm{f}$.

Kratz, D., Wendling, I., Nogueira, A. C., Souza, P. V. (2013). Propriedades físicas e químicas de substratos renováveis. Revista Árvore, Viçosa 37 (6): 1103 1113,2013

Lim, S. L., Lee, L. H. and Wu, T. Y. (2016). Sustainability of using composting and vermicomposting technologies for organic solid waste biotransformation: Recent overview, greenhouse gases emissions and economic analysis. Journal of Cleaner Production 111: 262-278.

Martins, C. S., Castro, P. M., Santos, E., Cunha, A. J. B., Santos, J. V., Porto, J. H., Bernardo, T., Carmo, R., Torido, B. (2011). Companhia Energética de Minas Gerais. Manual de arborização. Belo Horizonte: Cemig / Fundação Biodiversitas.

Ministério da Agricultura, Pecuária e Abastecimento (MAPA). Secretaria de Defesa Agropecuária (SDA). Instrução Normativa SDA No 17 de 21 de maio de 2007. Métodos Analíticos Oficiais para Análise de Substratos e Condicionadores de Solos. Diário Oficial da União, Brasília, DF, 24 de maio 2007.

Ministério da Agricultura, Pecuária e Abastecimento (MAPA). Secretaria de Defesa Agropecuária (SDA). Instrução Normativa SDA No. 25 de 23 de julho de 2009. Normas sobre as especificações e as garantias, as tolerâncias, o registro, a embalagem e a rotulagem dos fertilizantes orgânicos simples, mistos, compostos, organominerais e biofertilizantes destinados à agricultura. Diário Oficial da União, Brasília, DF, 23 de julho de 2009.

Oliveira, C. A., Sartori, R. H. and Garcez, T. B. (2008). Compostagem. Escola Superior de Agricultura Luiz de Queiroz-USP. Piracicaba.

Pereira Neto, J. T. (2007). Manual de compostagem: processo de baixo custo. Viçosa: ed. Universidade Federal de Viçosa.

Reis, M. F. P. (2005). Avaliação do processo de compostagem de resíduos sólidos urbanos. 239 f. Thesis, Universidade Federal do Rio Grande do Sul, Porto Alegre.

Röber, R. and Schaller, K. (1985). Pflanzenernährung im Gartenbau. Stuttgart: Ulmer.

Rocha, A. J. F., Souza, R. L. P., Reda, A. L. L., Silva, G. T. (2015). Destinação sustentável do resíduo da poda de árvores urbanas. Paper presented at XV Safety Health and Environment World Congress, Porto, Portugal.

Ros, C. O., Rex, F. E., Ribeiro, I. R., Kafer, P. S., Rodrigues, A. C., Silva, R. F., Somavilla, L. (2015). Uso de Substrato Compostado na Produção de Mudas de Eucalyptus dunnii e Cordia trichotoma. Floresta e Ambiente, Seropédica, 22 (4): 549 - 558.

Rossi, C. Q. (2013). Matéria orgânica do solo e fósforo orgânico em cronossequência de cana-de-açúcar cultivada no cerrado. Thesis, Pós-Graduação em Agronomia, Universidade Federal Rural do Rio de Janeiro, Seropédica.

Sá, F. V. S., Brito, M. E. B., Ferreira I. B., Antônio Neto, P., Silva, L. A. S., Costa, F. B. (2015). Balanço de sais e crescimento inicial de mudas de pinheira (Annona squamosa L.) sob substratos irrigados com água salina. Irriga, Botucatu, 20 (3): 544 - 556.

Santos Filho, R. C., Oliveira, L. C. F., Silva, V. M. F., Holanda, E. P. T. (2018). O aproveitamento de resíduos sólidos urbanos, por meio do processo de 
compostagem aeróbia enriquecida com casca de sururu. Ciências exatas e tecnológicas, 4 (3): 67 - 76.

Santos, P. L. F. and Castilho, R. M. M. (2016). Caracterização físico-química de diferentes substratos e sua influência no desenvolvimento da grama esmeralda. Tecnol. \& Ciên. Agropec., João Pessoa, 10 (6): 1-5.

Santos, T. C. G., Santos, L. A., Ximenes, T. C., Melo, A. M., El-Deir, S. G. (2015). Metodologia para o controle da compostagem em pequenas propriedades rurais. Paper presented at the VI Congresso Brasileiro de Gestão Ambiental, Porto Alegre, Brasil.

Sarruge, J. R. and Haag, H. P. (1974). Análise química das plantas. ed. Piracicaba: Escola Superior de Agricultura "Luiz de Queiroz"

Schäfer, G., Souza, P. V. S. and For, C. S. (2015). Um panorama das propriedades físicas e químicas de substratos utilizados em horticultura no sul do Brasil. Ornamental Horticulture, 21 (3): 299 - 306.

Schmitz, J. A. K., Souza, P. V. D. and Kämpf, A. N. (2002). Propriedades químicas e físicas de substratos de origem mineral e orgânica para o cultivo de mudas em recipientes. Ciência Rural, Santa Maria, 32 (6): 937 - 944.

Severino, L. S., Lima, R. L. S. and Beltrão, N. E. M. (2006). Composição química de onza materiais orgânicos utilizados em substratos para produção de mudas. Comunicado Técnico 278 - Ministério da Agricultura, Pecuária e Abastecimento, Empresa Brasileira de Pesquisa Agropecuária, Campina Grande.

Souza, C. C. B., Sobrinho, N. M. B. A., Lima, E. S. A., Lima, J. O., Carmo, M. G. F., García, A. C. (2019). Relation between changes in organic matter structure of poultry litter and heavy metals solubility during composting. Journal of Environmental Management, $247: 291$ - 298.

Teixeira, P. C., Donagema, G. K., Fontana, A., Teixeira, W. G. (2017). Manual de métodos de análise do solo. 3 ed. Brasília: Empresa Brasileira de Pesquisa Agropecuária.

Valente, B. S., Xavier, E. G., Morselli, T. B. G. A., Jahnke, D. S., Brum Jr, B. S., Cabrera, B. R., Moraes, P. O., Lopes, D. C. N. (2009). Fatores que afetam o desenvolvimento da compostagem de resíduos orgânicos. Archivos de Zootecnia, Córdoba, 58: 61.

Vieira, C. R., Weber, O. L. S. and Scaramuzza, J. F. (2014). Resíduos orgânicos como substrato para produção de mudas de guanandi. UNICIÊNCIAS, 18 (2): 91-97.

Zorzeto, T. Q. (2011). Caracterização física e química de substratos para plantas e sua avaliação no rendimento do morangueiro (Fragaria $\chi$ ananassa Duch.). Diss. Instituto Agronômico Pós-Graduação, Campinas.

Zorzeto, T. Q., Dechen, S. C. F., Abreu, M. F., Fernandes Júnior, F. (2014). Caracterização física e substratos para plantas. Bragantia, Campinas, 73 (3). 